( I. І. Конюхова, К.т.н., доцент, Р. В. Рибка, к.т.н., доцент, Українська академія друкарства, Львів, Україна

\title{
МАРКЕТИНГОВІ ДОСЛІДЖЕННЯ ВИГОТОВЛЕННЯ СУВЕНІРНИХ ПАКОВАНЬ
}

В статті наведено результати проведення аналітичного та маркетингового дослідження виготовлення сувенірних паковань $з$ картону, визначення потреб та побажань споживачів щодо оформлення паковань за розробленою анкетою та проведеними соціологічними опитуваннями.

Ключові слова: сувенірне паковання; аналітичне та маркетингове дослідження; соціологічне опитування; кореляційна матриця; картон; анкета; респонденти.

\section{Постановка проблеми}

Як відомо, паковання - це невід'ємна частина товару, що виконує захисну, транспортну й комунікаційну функції. Основними напрямками розвитку вітчизняного ринку паковання $€$ вдосконалення дизайну, оптимізація форми паковання й впровадження нових матеріалів для його виробництва. Все це дозволяє зробити транспортування, зберігання й реалізацію товару більш ефективними. Загальновідомо, що більшість споживачів купують товар, впізнавши паковання відомого товаровиробника. Диференціація паковання дає можливість залучити нові сегменти споживачів відповідно до рівнів доходів, віку, стилю життя, інших параметрів [1].

Що дає товару оригінальне паковання?

1. Паковання - один із елементів особливості бренду, емоційні відчуття, викликані пако- ванням, переносяться споживачами на фізичне сприйняття продукту.

2. Асоціативність. Грамотно зроблене паковання, як і будьяка гарна ідея, формує образ тільки одного бренду.

3. Розповідь. Добротне, гарне паковання здатне без слів переконати споживача купити продукт, так само, як неякісне і негарне здатна відштовхнути [4, 5].

\section{Аналіз попередніх досліджень}

Паковання - це вже оплачена виробником рекламна площина, дизайн якої слід розробляти як рекламне повідомлення, в якому $є$ основні й допоміжні елементи, першочергові та другорядні. Звичайно, сьогодні на деяких ринках самовпровадження бренду вже неможливо, рекламна підтримка може буде потрібна, але якщо у товару $є$ стильне паковання, економія рекламних коштів гарантована.

(C) $2016 \mathrm{p}$. 
Таким чином, при виготовленні будь-якого паковання потрібно пам'ятати добре відомий факт: паковання й продукт для споживача нероздільні. Високоякісний продукт у дешевому пакованні у буквальному значенні здається іншим на смак, ніж той самий, але в якісному [2].

\section{Мета роботи}

Метою даної роботи було проведення маркетингового дослідження виготовлення сувенірних паковань з картону, визначення потреб та побажань споживачів щодо оформлення паковань.

\section{Результати проведених досліджень}

Опитувальник складався з 10 питань, в кожному з яких було чотири варіанти відповідей. Також важливою інформацією для подальших статистичних розрахунків були вік, стать та працевлаштованість респондентів. Загальна кількість опитаних 135 осіб.

Методика проведеного дослідження сформована так, що відповіді на питання виражають повне схвалення (питання а), часткове схвалення (питання b), часткове несхвалення (питання c), повне несхвалення (питання d). І, відповідно до такого поділу, при розрахунку статистичних даних кожному варіанту відповіді присвоюються числові значення $-\mathrm{a}=3, \mathrm{~b}=2, \mathrm{c}=1 \mathrm{i} \mathrm{d}=0$.

При обробці результатів використані різноманітні методи математико-статистичного опрацювання емпіричних даних за допомогою комп'ютерної програми STATISTICA (версія 8.0).
Використано методи порівняльного аналізу за t-критерієм Стьюдента, однофакторного дисперсійного аналізу (аналіз варіацій та тест Шеффе), кореляційного аналізу (лінійна кореляція за Пірсоном), таблиці частот при рівні ймовірності $p<0,05$ [3].

Насамперед звертаємо увагу щодо статі опитуваних. Т-тест для загальної групи досліджуваних за показником «статі» показує, що жінки частіше зберігають паковання, яке їм сподобалось $(M=2,22)$, ніж чоловіки $(\mathrm{M}=1,32)$. А от кольору паковання більше уваги приділяють чоловіки ( $\mathrm{M}=1,44)$, ніж жінки $(\mathrm{M}=1,07)$. Це пояснюється тим, що жінки лояльніші до вибору кольору паковання, бо їх не обмежує поняття «нечоловічого» кольору. А от чоловікам необхідно підібрати подарунок так, щоб одразу було зрозуміло, що подарунок від кавалера.

У групі серед жінок, за критерієм «працевлаштованості», на колір сувенірного паковання більше уваги звертають працевлаштовані жінки $(\mathrm{M}=1,47)$ ніж непрацевлаштовані (M $=0,67)$. Таким чином, непрацевлаштовані виправдовують свою фінансову неспроможність витрачати зайвий кошт на паковання і схиляються до думки, що головне це подарунок.

Вікові показники даної категорії свідчать, що працевлаштовані жінки $€$ старшими ніж непрацевлаштовані, і це, відповідно, теж сприяє ствердженню конкретики кольору паковання.

У групі серед чоловіків за показником «працевлаштованості» не працевлаштовані чоловіки переважно не обізнані щодо 
підприємств-виробників паковань $(\mathrm{M}=0,8)$, на відміну від працевлаштованих (M = 1,3). Це може пояснюватись специфікою професії працевлаштоваHих.

Також згідно з отриманими результатами спостерігається, що працевлаштовані більш переконані у конкурентоспроможності вітчизняного виробника паковань ( $M=2,33$ ), ніж непрацевлаштовані, які здебільшого не компетентні з цього приводу.

Вікові показники даної категорії, також як і серед жінок, свідчать, що працевлаштовані чоловіки старші ніж непрацевлаштовані.

За показником «непрацевлаштування» жінки більше схильні до зберігання паковання, що сподобалась ( $\mathrm{M}=2,21$ ) ніж чоловіки (M = 1,32). Проте чоловіки, звертають увагу на колір паковання, якщо мають можливість $(\mathrm{M}=1,4)$, в той час як жінки не звертають на це уваги (M = 0,67). Непрацюючі жінки є більш обізнаними серед виробників паковань ( $\mathrm{M}=1,3)$, ніж непрацевлаштовані чоловіки ( $\mathrm{M}=0,8)$.

Серед працевлаштованих $€$ та ж сама тенденція, що і серед непрацевлаштованих - жінки більше схильні до зберігання паковання, що сподобалась (М $=2,24)$ ніж чоловіки ( $M=1,32)$. Серед чоловіків прослідковується більша впевненість, що вітчизняний виробник $є$ конкурентоспроможний $(\mathrm{M}=2,33)$, ніж серед жінок $(M=1,88)$.

Згідно t-тесту для загальної групи досліджуваних за показником «Кольору паковання» усіх респондентів поділено на дві групи: перша, для яких має значення колір паковання i друга - які не надають цьому уваги. Отже ті, хто звертає увагу на колір паковання, схильні вважати, що це впливає на статус того, хто дарує (M = 2,05) або варто хоча б звертати на це увагу. На відміну від тих, хто не приділяють уваги кольору паковання, які віддають перевагу твердженню, що паковання на статус не впливає, і все залежить від особистих побажань того, хто дарує $(M=1,65)$. Відповідно це підтверджується і результатами за питанням № 4, згідно з якими перша група, якщо випадає можливість, тоді намагатимуться обрати колір паковання $(\mathrm{M}=1,41)$, а друга група не звертає на це уваги ( $\mathrm{M}=1,00)$. Також, ті, хто звертають увагу на колір, схильні вважати, що якісне паковання так чи інакше $\epsilon$ запорукою якісного товару (M = 1,7). А ті, хто не звертають уваги на колір, схиляються до думки, що між пакованням і товаром зв'язку щодо якості немає $(\mathrm{M}=0,88)$, a то і навпаки, під красивим пакованням ховається неякісний товар.

Згідно з проведеним дослідженням респонденти, які звертають увагу на паковання при виборі сувеніру чи подарунку, також звертають увагу на колір паковання ( $\mathrm{M}=1,53)$. В той час, як респонденти, що не приділяють уваги вибору паковання, i відповідно, не звертають уваги на його колір $(\mathrm{M}=1,09)$.

Респонденти які вважають, що сувенірне паковання не впливає на статус того, хто дарує, вважають, що неякісний товар 
заангажовують гарним пакованням $(\mathrm{M}=1,00)$. А респонденти, що визнають вплив паковання на статус того, хто дарує, схиляються до думки, що елітне паковання, в переважній більшості, є запорукою якісного товару $(\mathrm{M}=1,61)$.

У групі досліджуваних, для яких колір у виборі паковання має значення, спостерігається тенденція, що вони звертають увагу на вибір паковання при обранні подарунку $(M=1,62)$ та схиляються до думки, що сувенірне паковання впливає на статус того, хто його дарує (M = 2,15). У іншій групі, для яких колір у виборі паковання не має значення, присутнє переконання, що паковання не впливає на статус того, хто дарує, або, принаймні, не є обов'язковим ( $\mathrm{M}=$ $=1,7)$. Також ця група респондентів схильні стверджувати, що при купівлі подарунку вони, переважно, не звертають уваги на паковання ( $M=1,22)$, проте щось оригінальне може їх зацікавити.

Досліджувані, які вважають, що якісно виготовлене паковання є запорукою якісного товару, схиляються до думки, що людині 3 відповідним статусом не обов'язково дарувати подарунок у відповідному подарунковому пакованні, проте вважають, що варто було це б робити $(\mathrm{M}=2,12)$. Також ця група більш обізнана у сфері виготовлення сувенірного паковання у Львові $(\mathrm{M}=1,35)$. Інша група досліджуваних, що не схильні прослідковувати взаємозв'язок між якісним пакованням та якісним товаром, припускають, що на статус того, хто дарує, сувенірне паковання не впливає $(\mathrm{M}=1,61)$. Досліджувані цієї групи менш обізнані щодо виробників паковань $(\mathrm{M}=1,02)$.

Згідно однофакторного дисперсійного аналізу (аналіз варіацій та тест Шеффе) за питанням № 5 (що стосується вибору кольору для паковання), спостерігаються такі результати. Досліджувані, які надають перевагу пастельним кольорам у виборі паковання, частіше його зберігають $(\mathrm{M}=2,34)$, порівняно 3 тими, хто обирає холодні відтінки $(\mathrm{M}=1,29)$. Ті респонденти, які надають перевагу яскравим тонам паковань, також схильні до їх зберігання, проте досить рідко $(\mathrm{M}=1,86)$. Ця ж група старається при можливості самостійно обирати колір подарункового паковання $(\mathrm{M}=1,83)$, в той час як групи, що обрали пастельні (M = 1,1) та холодні ( $\mathrm{M}=1,29)$ тони не надають цьому значення.

Провівши розрахунки методом кореляційного аналізу (лінійна кореляція за Пірсоном), як видно з рис., що всі взаємозв'язки між показниками $\epsilon$ прямопропорційними. Аналізуючи ці кореляційні зв'язки спостерігаємо, що чим більше сувенірне паковання впливає на статус того, хто його дарує, тим більше колір цього паковання впливає на вибір людини ( $r=$ $=0,241)$, на її готовність переплатити за якісне паковання ( $r=$ $=0,183)$, на переконання, що якісно виготовлене паковання $\epsilon$ запорукою якісного товару $(r=$ $=0,326)$, на обізнаність у виробниках сувенірних паковань на Львівщині $(r=0,238)$ та на переконання про конкурентоспро- 
можність вітчизняного виробника $(r=0,202)$. Готовність переплатити за якісне паковання прямопропорційно пов'язано 3 впевненістю у конкурентоспроможності вітчизняного виробника $(r=0,195)$. В свою чергу конкурентоспроможність впливає на звертання уваги на колір при виборі паковання $(r=0,173)$ та на обізнаність у виробниках сувенірних паковань на Львівщині $(r=0,272)$, яка в свою чергу пов'язана з переконанням, що якісне паковання - запорука якісного товару $(r=0,223)$. А ті, на чий вибір паковання впливає колір, при виборі подарунку звертають увагу на паковання $(r=0,228)$.

\section{Висновки}

Згідно з даними результатами, можна зробити такі висновки, що переважна більшість респондентів при виборі пако- вання звертають увагу на оригінальне паковання. Прослідковується тенденція до зберігання паковання, яке сподобалась. Також більшість досліджуваних вважають, що сувенірне паковання впливає на статус того, хто дарує. Щодо кольору, то респонденти приблизно розділились на дві групи: ті, хто обирають колір паковання при можливості та ті, що вважають, що не колір паковання, а подарунок це головне. Проте відсоток тих, хто б обирав колір паковання, базуючись на самому подарунку, менший порівняно з тими, хто обрали конкретні кольори паковань. Готовність споживачів переплачувати за паковання базується на його неодмінній особливості та якості. Думки щодо того, що якісне паковання $\epsilon$ запорукою якісного товару, розділились: одна частина вважає,

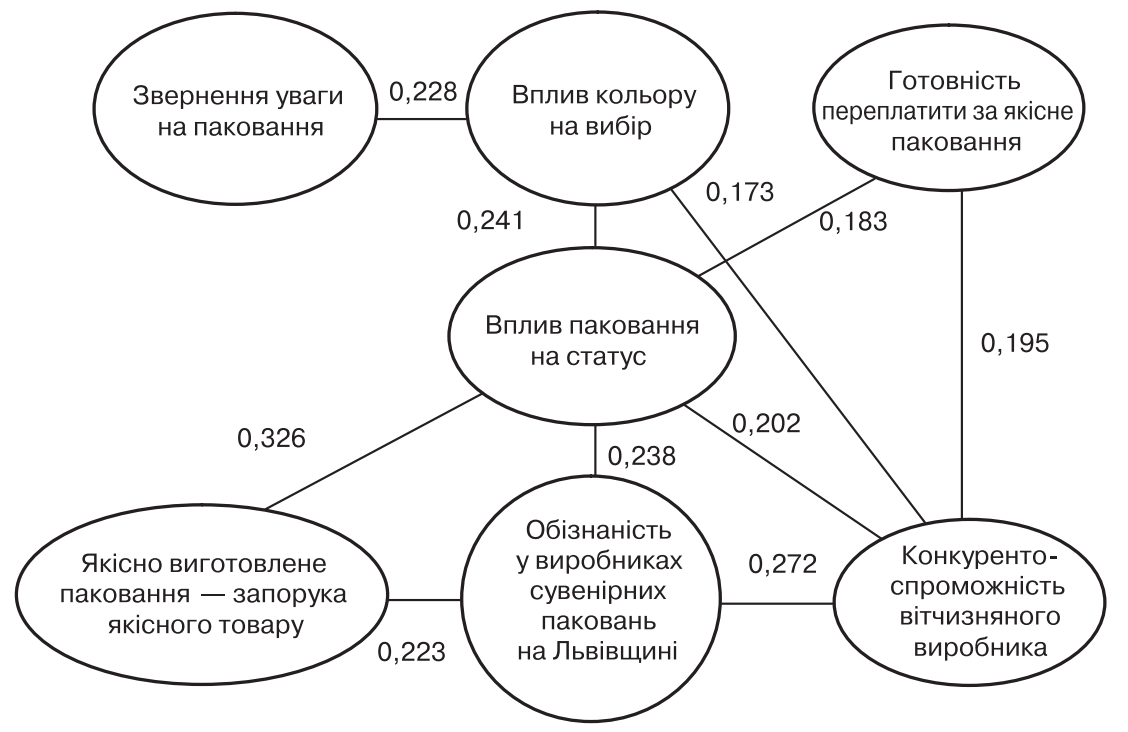

Кореляційна матриця для групи досліджуваних за різними показниками при $\mathrm{p}<0,05$ 
що це справді так, а інші - що одне на інше не впливає. Ознайомленість з підприємствами-виробниками відсотково $€$ доволі низькою, але більшість вважають, що наш вітчизняний виробник $€$ конкурентоспроможним. Матеріалом для сувенірного паковання більшістю було обрано картон.

\section{Список використаної літератури}

1. Шредер В. Л. Упаковка из картона / В. Л. Шредер, С. Ф. Пилипенко. Киев : ИАЦ «Упаковка». - 2004. - 388 с.

2. Креатив в дизайне упаковки и его возможности [Електронний ресурс]. - Режим доступу : http://nnm.ru/blogs/modestop/.

3. Бабенко В. В. Основи теорії ймовірностей і статистичні методи аналізу даних у психологічних і педагогічних експериментах / В. В. Бабенко [Навч. видання]. - Львів : ЛНУ ім. І. Франка. - 2006. - 170 с.

4. Що таке елітна упаковка? / [О. Горбяк] // Світ упаковки. - 2007. - № 2(54). - С. 54-55.

5. Удріс Н. С. Упаковка : засіб справити враження / Н. С. Удріс // Упаковка. - 2012. - № 3. - С. 67-70.

\section{References}

1. Shreder, V. L. \& Pilipenko, S. F. (2004). Upakovka iz kartona [Cardboard packaging]. Kiev: IAC 'Upakovka' [in Russian].

2. Kreativ v dizajne upakovki i ego vozmozhnosti [Creative design of packaging and its capabilities]. Retrieved from http://nnm.ru/blogs/modestop/ [in Russian].

3. Babenko, V. V. (2006). Osnovy teorii ymovirnostei i statystychni metody analizu danykh u psykholohichnykh i pedahohichnykh eksperymentakh [Fundamentals of probability theory and statistical methods of data analysis in psychological and educational experiments]. Lviv: LNU im. I. Franka [in Ukrainian].

4. Horbiak, O. (2007). Shcho take elitna upakovka? [What is luxury packaging?]. Journal of Svit upakovky. - The world of packaging, 2(54), 54-55 [in Ukrainian].

5. Udris, N. S. (2012). Upakovka: zasib spravyty vrazhennia [Packaging: to impress]. Journal of Upakovka. - The Packaging, 3, 67-70 [in Ukrainian].

\section{В статье приведены результаты проведения анали- тического и маркетингового исследования изготовления сувенирных упаковок из картона, определение потреб- ностей и пожеланий потребителей по оформлению упаковок по разработанной анкете и проведенным социологическим опросам.}

\section{Ключевые слова: сувенирная упаковка; аналитическое} и маркетинговое исследование; социологический опрос; корреляционная матрица; картон; анкета; респонденты. 
The article presents the results of analytical and market research of manufacturing process of souvenir cardboard

packaging, identification of the needs and desires of consumers in packages decoration by the developed questionnaire and the conducted polls.

Keywords: souvenir packaging; analytical and marketing research; poll; correlation matrix; cardboard;

questionnaire; respondents.

Рецензент - О. В. Зоренко, к.т.н., доцент, КПІ ім. Ігоря Сікорського

Надійшла до редакції 25.11.16 